\title{
A EDUCAÇÃO EM DUQUE DE CAXIAS SOB O OLHAR DA IMPRENSA ESCRITA: DISCUSSÃO EM TORNO DA EDUCAÇÃO PRIMÁRIA E DA FORMAÇÃO DE NORMALISTAS (ANOS 1950)
}

\author{
Antoniette Camargo de Oliveira ${ }^{1}$ \\ Universidade Federal de Uberlândia - (UFU) \\ Wenceslau Gonçalves Neto ${ }^{2}$ \\ Universidade Federal de Uberlândia (UFU); Universidade de Uberaba (UNIUBE)
}

\begin{abstract}
RESUMO
Buscamos analisar alguns artigos levantados na imprensa escrita da cidade de Duque de Caxias, a respeito da educação. Nessa perspectiva saltaram aos nossos olhos especialmente aqueles problemas relativos à década de 1950: a força das instituições particulares, subvencionadas pelo município; as dificuldades para a prática de inspeção; o interesse do governo em relação ao ensino técnico; e ainda escassez de docentes, falta de água encanada, falta de espaço, de escolas, de transporte público escolar, o analfabetismo, as desistências, a distorção idade/série, e outros. Assim, consideradas a quantidade e a importância das reportagens, demos destaque à demanda por normalistas de um curso criado em 1954, anexo ao atual Colégio Santo Antônio em Duque de Caxias e dirigido pelas Irmãs Franciscanas de Dillingen. Destacamos ainda a resistência da Prefeitura em contratá-las, assim como as pressões políticas veiculadas pela imprensa para a realização de concursos em contraponto à simples contratação das recém-formadas normalistas.
\end{abstract}

Palavras-Chave: História da Educação; Imprensa; Duque de Caxias.

\section{ABSTRACT}

We analyze some articles in the press raised the city of Duque de Caxias, about education. From this perspective sprang to our eyes especially those problems relating to the 1950's: the power of private institutions, subsidized by the municipality, the difficulties in the practice of inspection, the government's interestin relation to technical education, and even shortages of teachers, lack piped water, lack of space, schools, public transportation school, illiteracy, dropouts, theage / grade, and others. Thus, considering the amount and importance of the reports, we highlighted the demand for normalistas a course created in 1954, annexed to the current San Antonio College in Duque de Caxias and directed by the Franciscan Sisters of Dillingen. We also highlight the strength of the City to hirethem, as well as political pressures in the press to conduct competitions in counterpoint to the simple hiring of newly formed normalistas.

Keywords: History of Education; Press; Duque de Caxias.

A escrita deste artigo teve por objetivo compor um quadro analítico a respeito da educação em Duque de Caxias-RJ, buscando primordialmente demonstrar as principais discussões que ocorriam na imprensa local e suscitar novos trabalhos sobre a temática. Nessa busca, dentre outros aspectos, foi possível perceber que as empresas jornalísticas nem sempre tiveram uma divisão organizada do trabalho, com separação de editorias, tipos de notícias, redatores especializados em determinados assuntos, enfim; o que certamente era comum à maioria dos jornais escritos da época. Por outro lado, é notória nas reportagens da década de 1950 a importância dedicada pelos articulistas à educação, enquanto um dos problemas que mais afetava as pessoas em seu cotidiano; o que não deixava de ser comum também em outros centros urbanos ${ }^{3}$. Nessa perspectiva, concordamos com Elcias Lustosa, para o qual 
A editoria de cidade, assim como a editoria nacional, é a clínica geral da redação. Ali se aborda todos os assuntos. Tudo que não for de uma editoria especializada e ocorrer na cidade em que se edita o veículo de comunicação de massa vai para a editoria de cidade (1996, p. 141).

Nas décadas de 1930 e 1940 foram encontrados muito poucos artigos que contribuíssem para desvelar a situação da educação em Duque de Caxias. Na maioria são propagandas de escolas ou professores particulares ou ainda artigos sobre assuntos específicos, como, por exemplo, uma reforma ortográfica luso-brasileira que ocorreu em 1931; um Conselho de Educação do Estado do Rio de Janeiro que foi criado em 1932, o qual se responsabilizaria por opinar sobre o ensino primário, secundário e profissional. Em 1948 era lançada a Campanha Nacional da Criança, sob a presidência da então primeira dama do Estado, na busca por sanar problemas básicos como as endemias (peste branca, sífilis e mal de Hansen), a sub-alimentação e a alfabetização ${ }^{4}$. É importante lembrar que se tratava do período varguista no qual a censura era evidente, conforme Capelato,

(...) o esforço de politização, de eliminação de vozes discordantes e de penetração em todos os setores realizou-se sobretudo através da imprensa periódica e, em menor medida, através do rádio (1999, p.173).

Isto ajuda a compreender o pequeno número de artigos encontrados a respeito dos problemas educacionais nessas duas décadas. Destaque-se sobre a imprensa escrita na Baixada Fluminense que, pelo menos ao se referir à educação, seus articulistas nos diversos jornais em que colaboravam, pelo menos aparentemente buscavam servir à "causa pública" (SOBRINHO, 1997, p.186). Ou seja, com exceção da década de 1930 e grande parte de 1940 — quando eram pouco noticiados os problemas educacionais, seja devido à autocensura instituída pelo governo Vargas, ou talvez pela educação ainda não ter ganhado destaque efetivamente enquanto um problema naquele contexto da Baixada — os artigos e reportagens tornaram-se formadores de opinião; principalmente a partir da década de 1950, quando focaremos o município de Duque de Caxias com seu Folha de Caxias (posteriormente Folha da Cidade). Este semanário, apesar de órgão oficial da Associação Comercial de Duque de Caxias, órgão classista, pelo menos no que tange à educação, mostrou-se um instrumento ativo de opinião pública (ZICMAN, 1985, p.91).

Pela Constituição de 1934, a preocupação maior no que se referia à publicação de periódicos era em relação às ameaças externas, bem como à sua "má utilização" no sentido de promover insurreições, mas também como forma de proteger o governo em relação às críticas e movimentos opositores. Possivelmente esteja aí a explicação inicial para os poucos artigos opinativos (no caso sobre educação) até meados de 1950; talvez se evitasse escrever como forma de prevenção da esperada censura. E conforme já se adiantou, antes da década de 1950 na Baixada Fluminense praticamente apenas se noticiava alguma campanha, reforma ou órgão, lançados ou criados pelo próprio governo, além de uma ou outra propaganda de escolas particulares.

A preocupação com as ameaças externas continuava pela Constituição de 1937, no entanto, a imprensa passa a ser submetida ainda de forma mais enfática em termos de censura. Sob a capa da proteção à infância e juventude, em termos de moral e bons costumes, o governo ditatorial implantado queria, na verdade, se autoproteger contra seus opositores.

$\mathrm{Na}$ constituição de 1946, conforme o Artigo 141 e seu parágrafo $5^{\circ}$, bem como seu Artigo 160, apesar de a censura já estar minimizada, ainda prevalecia o receio em relação aos estrangeiros e suas possíveis ideias subversivas. De qualquer forma, o afrouxamento das leis 
opressoras, possibilitou o aumento da quantidade de artigos de opinião na Baixada Fluminense, justamente o momento a partir do qual se levantou a maior quantidade de reportagens referentes à educação e seus problemas.

Não foram percebidos posicionamentos diferentes que possibilitassem estabelecer comparações entre um e outro órgão de imprensa ou, como diria Renée Barata Zicman (1985, p.97), não seria possível fazer um estudo "inter-jornais"; além do mais, diferentemente da Folha da Cidade, os outros jornais, não tiveram tanto destaque em termos de quantidade de artigos publicados especificamente sobre a problemática educacional; assim, de uma forma ou de outra, a referida proposta restaria inviabilizada.

Em todo caso, em alguns momentos percebeu-se que determinados articulistas evitavam certos posicionamentos e consequentes constrangimentos, conflitos ou antipatias, fossem estes por questões pessoais, políticas ou ideológicas; o que é demonstrativo do tipo de relação entre o articulista e a empresa jornalística, - aquele muitas vezes apenas um colaborador esporádico, sem nenhum vínculo ou contrato empregatício, — ou ainda da relação de dependência entre o jornal e as empresas ou instituições pagadoras de publicidade, cujos interesses poderiam não coincidir com a real opinião dos articulistas.

Dentre os temas ligados à educação e que receberam maior destaque na imprensa duquecaxiense, ou cujos assuntos foram mais frequentemente publicados, podemos apontar: $1^{\circ}$ ) para a força que tinham as instituições educacionais particulares, geralmente subvencionadas pelo poder público municipal devido a escassez de escolas públicas ${ }^{5} .2^{\circ}$ ) para as dificuldades que os inspetores escolares tinham para desenvolver seu trabalho, uma vez que havia um único inspetor para a grande quantidade de escolas no município e seus distritos, além das longas distâncias entre uma e outra instituição, e até pelas más condições das estradas e ruas públicas ${ }^{6} .3^{\circ}$ ) para o interesse do governo em relação ao ensino técnico, voltado para a classe trabalhadora ${ }^{7} .4^{\circ}$ ) E ainda para outros problemas, tais como falta de professores, falta de água, falta de espaço, transporte público escolar, analfabetismo, desistência, distorção idade/série, e outros ${ }^{8}$. Entretanto, um tema em especial nos chamou a atenção, do qual se tratará a seguir.

\section{Demanda por Normalistas na Educação Fluminense}

A educação começou a ser motivo de preocupação mais efetiva na imprensa de Duque de Caxias-RJ apenas a partir da década de 1940, em coincidência com o período de fundação do atual Colégio Santo Antônio, criado e dirigido pelas Irmãs Franciscanas de Dillingen, uma Congregação católica feminina, cujas primeiras Irmãs vieram da Alemanha para o Brasil em 1937. Antes disso o setor era realmente bastante precário naquela cidade. Na década de 1950 um problema apontado na imprensa escrita era o aproveitamento de professores(as) leigos(as) para lecionarem nas então escolas primárias.

As escolas primárias mantidas pelo Municipio estão, cada vez mais desensinando as creanças, mesmo porque, na longa prática dos tempos, verificou-se que a instrução necessita de técnicos e nunca se aproveitam leigos para funções de formadores do espírito das creanças.

Aqui em Duque de Caxias se desvirtua o problema mais sério do Brasil e se lega à segundo plano a instrução primária da maneira mais displicente possivel, tanto no material, adaptação, pedagogia como no próprio elemento aproveitado para exercer o magistério. [...]

[...] temos também certesa absoluta que existem alguns, que, na mais manifesta demonstração de cegueira e desconhecimento da matéria chegam a afirmar que o magistério Municipal devia ser exercido por leigas porque as professoras diplomadas querem ganhar muito mais. 
Na opinião "abalisada" desse nosso Licurgo deviam-se fechar as escolas normais primárias porque o estudo de especialização das educadoras de nada serve, deves que qualquer uma senhorita, pouco além de analfabeta, têm poderes e direitos para lecionar, o que, muita vês não sabe. Quer dizer, ao fim, que a Prefeitura Municipal de Duque de Caxias, pela opinião do sr. Moura pode diplomar qualquer pessoa, pois já se transformou em uma escola normal, sob a direção do eminente legislador. [...] (Comentário sobre o Ensino. O Municipal, Duque de Caxias, Ano II, n.54, 25 ago. 1951, p.04).

Com um número cada vez mais elevado de matérias desnecessárias à vida prática e com um método de ensino em crescente depreciação, além de uma decadência notória do grau de capacidade do professor, tudo isso é motivo para a cultura da nossa juventude regredir assustadoramente, a ponto de preocupar a alguns homens conscientes que por ventura existem nesse Brasil (Novos Rumos para o ensino primário municipal - está aquém das necessidades pedagógicas. A Folha de Caxias, Duque de Caxias, Ano I, n.15, 29 nov. 1953, p.01).

Como se percebe, o problema da falta de qualidade, geralmente atrelado à troca de favores, perdurou até a década de 1950 pelo menos, quando a preocupação com relação a uma formação diferenciada para aqueles que exerceriam a profissão docente, ficava cada vez mais evidente. Não cabia mais ou não eram mais admissíveis as praticadas e frequentes nomeações, as quais muitas vezes foram denunciadas como pistolões ${ }^{9}$, partidarismo, "politicagem" e outros. Essa interelação de interesses do contexto político e sua influência sobre a imprensa nos é lembrada por J. Péricles Diniz (2008, p. 7):

Condicionada pelas especificidades que lhe conferem personalidade própria, a narrativa jornalística opera com a atribuição de sentidos e a criação de valores que funcionam como intermediários das relações de poder na sociedade. Mas para lograr atribuir sentido ao discurso é preciso primeiro levar em consideração as condições de sua produção, o seu contexto. A partir daí, será possível identificar seus protagonistas e distinguir o seu objeto. A maneira como dado discurso estabelece sentidos e provoca efeitos depende da relação entre seus sujeitos, seus interlocutores, e aquilo a que se refere, o seu referente. O jornalismo, neste sentido, é um discurso autoritário em seu modo de funcionamento e em sua ideologia, marcada pela pressuposição da verdade e da neutralidade.

Até que ponto ou em que medida a neutralidade era inerente aos escritos jornalísticos publicados na Baixada a respeito da educação? As reportagens indicam que para alguns aspectos desse problema, vários dos articulistas aqui citados apareciam como neutros em suas críticas e questionamentos. Cobravam por lisura, qualidade, honestidade, não importava a quem ou a que órgão. Deve-se considerar, nessa perspectiva, o contexto político, cuja abertura ou liberdade, diferenciava-se do anterior período, então sob a batuta de Vargas.

A reivindicação pela qualidade e não apenas da quantidade também ficava clara noutro artigo:

O analfabetismo é um opróbio que muito nos envergonha. Há analfabetos de todos os quilates entre nós, porém os que infundem maior piedade e lástima são os que nem os nomes podem escrever. São milhões de irmãos imersos nessa noite de escuridão. Por isso cuida-se açodadamente, de inventar-se escolas. Quanto mais existir melhor. Inventam-se cursos de toda sorte porque 
precisa-se de uma fórmula instantânea de apressar a autora de muitos milhares de brasileiros. Nessa pressa desastrosa, descura-se do aspecto dos mais importantes do ensino: da sua QUALIDADE.

Há municípios que se ufanam de figurarem nos quadros estatísticos oficiais como sendo dos que mais possuem escolas, dando a impressão de que tôdas elas estão resolvendo SATISFATÒRIAMENTE, o grave problema da alfabetização. Chega-se porém, ao momento do ajuste de contas e tudo não passa de um grande "Bluff". Assim foi visto no "test" eleitoral de 1950, quando o eleitorado de modo algum correspondeu às estimativas dos organismos oficiais. Esperava-se que, em consequiência da forte campanha de alfabetização, bem maior fosse o comparecimento às urnas. Havia a perspectiva da presença de um grande contingente de eleitores novos em folha, safra quentinha das muitas centenas de escolas públicas instaladas à última hora. $\mathrm{O}$ drama atual, passados 5 anos, não difere do que descrevemos. A luta pela alfabetização prosseguiu, porém não cremos que os seus resultados tenham sido auspiciosos, isso porque só se está cuidando da quantidade, em detrimento da qualidade.

Em Caxias, pelo menos, essa tendência errônea e perigosa assume proporções de escândalo. A Prefeitura Municipal desde outras administrações, sustenta numerosas escolas que não correspondem de modo algum, às suas nobres finalidades. Sabe-se que as deficiências originam-se de vários motivos. Ora porque falta material adequado, ora porque os professores não estão à altura e não pode ser melhor porque miseráveis são os salários, ora porque sendo escola pública, seus mestres não se interessam de levar a sério o sacerdócio que abraçaram. $\mathrm{Na}$ verdade, poucas são as escolas da Cidade que possuem renome. O que há é muita gente sem capacitação para julgar ou então conveniências políticas sufocando e impedindo críticas aos males das nossas casas de ensino.

Essa anormalidade estende-se também ao ensino particular. [...] (Ensino Primário - Quantidade só, não; também qualidade. A Folha de Caxias, Duque de Caxias, Ano I, n.23, 07 fev. 1954, p.03).

É bom lembrar que foi apenas a partir da Constituição de 1988 que o analfabeto passou a ter direito ao voto. O que, por sua vez, revela que tal problema não tinha sido resolvido até pelo menos final do século XX. Quanto à questão da qualidade do ensino, o artigo demonstra o quanto já estava no limite tal situação em Caxias e o quanto se ansiava por professores(as) formados(as), ou seja, normalistas. Por outro lado, a problemática salarial dos docentes também era trazida à tona, bem como o indicativo da docência enquanto sacerdócio, o que hoje é tão criticado pela categoria. Surge também, ao final da transcrição, a questão das "conveniências" políticas.

Do problema da laicidade do professorado, incansavelmente abordado pela sessão "A Folha Escolar", passa-se à valorização das Escolas Normais:

Há entre alguns chefes de poder executivo, como também entre membros do poder legislativo dos Municípios do nosso Brasil, a convicção de que qualquer pessoa, por mais sumária que seja a sua instrução, poderá ser investida nas funções de professor primário, e muito especialmente, de professor de alfabetização.

Eles defendem essa tese, achando desnecessária a nomeação de um professor legalmente habilitado para o exercício do magistério, tendo em vista que os professores assim credenciados, querem ganhar um ordenado exorbitante, vindo encarecer demais o ensino e que os leigos aceitam vencimentos menores. 
Eis aí o engano. O ensino entregue aos leigos, fica bem mais caro ao Município do que quando entregue a professores, pelas razões que seguem: Um professor formado por uma ESCOLA NORMAL, ao lado das cadeiras de formação humanística, recebe ensinamentos de psicologia e de pedagogia onde aprende sob a vigilância de mestres experimentados, a transmitir as noções adquiridas, através de aulas ministradas pelos professores aos alunos das escolas primárias anexas ás ESCOLAS NORMAIS.

O tempo gasto na alfabetização de uma turma por um professor, chega a ser a quarta parte do tempo consumido por um leigo. Exemplificando: si um professor conseguir alfabetizar uma turma em seis meses, o leigo só o conseguirá em dois anos. Dessa forma, o fator tempo é bastante ponderável, de vez que as populações dos Municípios são constituídas de gente pobre e que não pode deixar um filho ser alfabetizando por uma eternidade, terminando por retirar a criança do colégio, côncio de que ela não tem pendor para o estudo. Desse modo, perde o BRASIL um grande número de seus filhos, estagnados pela ignorância.

Professores do BRASIL! Salvemos os nossos compatrícios das garras da insensatês dos maus brasileiros (PEREIRA, Prof. Roberto. A "Folha" Escolar. Folha de Caxias, Ano II, n.63, 19 jun. 1955, p.02).

No artigo seguinte o articulista escancara ainda mais a falta de preparo, tanto dos professores públicos municipais quanto, principalmente, dos da rede particular. Entretanto, o jornal se resguarda de qualquer crítica, afirmando que há as exceções. Ou seja, além dos de "inegável incapacidade" haviam os de "reconhecida competência". As normalistas continuavam apontadas como a melhor saída, assim como se aconselhava mudanças nos critérios de nomeação, principalmente por meio de concursos.

Não sabemos bem da legislação que rege o ensino no município de Caxias. Nem tão pouco do critério adotado para nomeação de professores municipais. Entretanto, pelas conclusões que podemos tirar das nossas observações, não é muito lisonjeira a situação do ensino primário municipal, quer particular, quer oficial. Não raro deparamos com mestres improvisados, sem qualquer lastro de cultura, indivíduos de patente mediocridade, que em outra cidade estariam bem freqüentando uma quarta série primaria. Despidos de conhecimentos didáticos, pedagogicos e intelectuais, mas que, apezar de tudo, ministram aulas a toda uma coletividade infantil, não sabemos se a educando para a vida ou se a embromando em nome da cultura.

Nos estabelecimentos particulares, então, a coisa se agrava. Conhecemos professores que francamente se dariam diante de uma pergunta mais acurada de um aluno estudioso. Professores que nós jamais reconhecemos como tal, antes de o serem, que qualquer individuo medianamente culto será capaz de reconhecer como ineptos.

São justamente, os aproveitados pelas escolas mais modestas, que escolhem os professores de acordo com seus recursos... Há as exceções.

Também no ensino oficial primário a coisa não vai às maravilhas. Ao lado das mestres de reconhecida competencia, alinham-se outras de inegavel incapacidade.

Dir-se-á que a Prefeitura não pode pagar o preço exigido pelas normalistas. Cobrarão tão caro? Não cremos. Pelo menos, muitas aí estão, trabalhando sem exigir mais que as suas colegas de conhecimentos inferiores.

O que aconselhamos é um outro critério para nomeação de professoras. Um concurso, por exemplo. Quanto às escolas primarias a Inspetoria Municipal deve estender a elas o seu raio de fiscalização, a fim de evitar um mal grave, 
pois que com reflexos danosos no futuro (Por uma Cultura Sólida da Infância. A Folha de Caxias, Ano II, n.68, 24 jul. 1955, p.01).

A questão das instituições escolares particulares é trazida para o debate, juntamente com as públicas, por ambas serem passíveis de contratar professores(as) desqualificados(as), seja sob a justificativa dos parcos recursos para remunerá-los(as), seja pela falta de fiscalização, que levava à frouxidão na hora das contratações. Em relação a isso, logo em outubro de 1955, sai uma nota de aviso em que a prefeitura passaria a fiscalizar as escolas particulares.

Procurada pela reportagem do jornal Folha de Caxias, D. Regina Tescaro Sampaio, então inspetora municipal de ensino declarava que:

esta fiscalização tem sido tentada por várias vezes e que motivos de ordem política têm impedido a sua realização. Agora, porém, todas as escolas primárias particulares serão fiscalizadas rigorosamente, sendo exigido o registro obrigatório dessas escolas na Inspetoria do Ensino. [...]

"Só com uma rigorosa fiscalização sôbre todas as escolas [...] poderemos moralizar o ensino neste município. Tenho visto em diversas escolas coisas incríveis: professoras que não sabem sequer escrever, ensinando às crianças". Disse ainda D. Regina que as professoras municipais são prejudicadas por este número calamitoso de professoras particulares sem capacidade, pois as professoras municipais também são arroladas pela opinião pública no número destas incapazes e a responsabilidade afinal vem a cair sôbre a Inspetoria do Ensino e sôbre a Prefeitura.

Finalmente disse D. Regina: "Tenho apelado aos pais para que, quando tiverem alguma dúvida, venham aqui pedir-me esclarecimentos. Eu os receberei com muito boa vontade, como os tenho recebido até hoje. Mas, não entreguem os seus filhos a professoras sem instrução, pois aprender errado é pior que a ignorância" (A Prefeitura fiscalizará as escolas particulares. A Folha de Caxias, Duque de Caxias, Ano III, n.81, 23 out. 1955, p.02).

Aqui fica claro que não havia número suficiente de inspetores de ensino que dessem conta de todas as instituições escolares; daí pedir ajuda dos pais dos alunos. Também se poderia questionar o fato de que apenas as escolas particulares seriam fiscalizadas, já que o artigo transcrito anteriormente indicava que as escolas de uma maneira geral precisavam passar pela dita moralização. A estes artigos todos, os quais apontam para os problemas relativos à falta de formação necessária ao exercício da docência, acrescenta-se um que parecia indicar a solução de todos os obstáculos pedagógicos relativos ao ensino primário de Duque de Caxias:

[...] A Escola Normal Santo Antonio foi fundada no início do ano passado, com uma turma de cerca de 30 alunas, na sua maioria ex-alunas do Ginasio Santo Antônio, [...]. O curso é oficializado e fiscalizado pelo governo do estado, sendo mantido - assim como o ginásio — pela dedicação incansável das irmãs Franciscanas.

Duque de Caxias portanto terá, a partir de 1956, anualmente, novas batalhadoras contra o analfabetismo, que se dedicarão a levar a luz do saber as pequenas mentes que se formam para a vida. [...]

O futuro da nossa cidade ficará, pois, sob responsabilidade dessas moças. Delas dependera a formação do caráter e da mentalidade dos homens de amanhã, e elas têm consciência dessa responsabilidade, tanto que se dedicam com afinco aos estudos e a par disto, algumas já praticam o ensino nas escolas primarias do municipio. [...] 
"Tendo estudado em Caxias, ficarei ensinando em Caxias". Disseram-nos Maria Nancy Almada, que já leciona no curso primário do Ginásio Santo Antônio e Maria Hobertina que já é professora municipal. [...]

Perguntamos ainda as gentis normalistas que diziam sobre a criação do curso normal em Caxias. Todas foram unânimes em afirmar que foi "algo maravilhoso", pois veio a solucionar o problema das professoras primárias em Caxias.

"Foi algo maravilhoso que veio impedir as pessoas quase analfabetas usem do titulo de professora" Disse a Maria Nancy. Enquanto Ely afirmou "foi ótimo porque é possivel que diminua assim o número de 'fessoras' e aumenta o de "professoras"" (As primeiras professoras formadas em Duque de Caxias. A Folha de Caxias, Duque de Caxias, Ano III, n.82, 30 out. 1955, p.01 e 03).

É importante frisar, portanto, que quem oferecia o Curso Normal em Duque de Caxias era uma instituição de cunho confessional. Ao afirmar sobre a consciência que tinham a respeito de sua responsabilidade para com o futuro da educação no município, o articulista deixa escapar que algumas alunas, antes mesmo de se formarem professoras, já davam aulas: uma delas na própria escola em que cursou o Ginasial, o que demonstra que a referida escola, confessional, dava preferência àquelas a quem tinha formado na hora de contratar algum(a) docente, certamente para dar continuidade aos seus ideais de ensino; e outra numa escola municipal, o que leva a crer que realmente não havia uma inspeção ou que não se exigia uma formação mínima para o exercício da docência nas escolas públicas ou particulares, devido certamente ao número insuficiente de professoras formadas. No final, ao afirmarem que o Curso vinha solucionar o problema das professoras primárias em Caxias, inclusive com pilhérias a respeito, presume-se o alcance das informações jornalísticas; assim, o fato de serem as primeiras docentes formadas em Duque de Caxias e diante das críticas às "professoras" não formadas, as enchia (às estudantes da Escola Normal do Colégio Santo Antônio) de orgulho e confiança.

Todos os artigos até este momento indicam os percalços e reivindicam as alternativas para sanar os mesmos no campo da educação. O principal de tais problemas seria a formação das professoras e a forma como eram admitidas nas mais diversas instituições de ensino. Após o anúncio da existência de uma Escola Normal na cidade de Duque de Caxias, bem como sua primeira formatura para o ano de 1956, começa então uma cobrança para que os órgãos públicos viessem a admitir, através de concurso, tais professoras formadas em Caxias:

Longe de nós o desejo de denegrir as professoras municipais, negando a cultura, os conhecimentos que a sua grande maioria possui. Há realmente professoras capazes em Caxias. Mas não se va dizer que não existam professoras semi-analfabetas, desconhecedoras dos mais elementares princípios pedagógicos que devem nortear qualquer educadora. Não só no ensino particular, como no municipal primário, para falar só deste, mocinhas inexperientes, apenas com o curso de admissão ou ginasial incompleto, ministram aulas a dezenas de crianças, que amanhã estarão irremediavelmente frustradas no prosseguimento dos estudos em cursos superiores. E' uma situação vexatória para o nosso município, que na matéria, não encontra similar por essas zonas. E o pior e quando são as mesmas efetivadas, conseguindo uma estabilidade que para a nossa infância é danosa, quase trágica.

A Prefeitura deve adotar o concurso para a admissão das professoras municipais. O momento e oportuno, quando 14 cargos foram agora criados. Quanto as escolas particulares, o processo não deve ser muito diferente. 
A propósito: como serão admitidas, num quadro completo, as primeiras professoras formadas em Caxias, no ano que vem? (Professoras Analfabetas. A Folha de Caxias, Duque de Caxias, Ano III, n.83, 06 nov. 1955, p.01).

A denúncia geral em relação às professoras analfabetas ou semi-analfabetas continua, mas agora não é mais a grande maioria que é incapaz, inverte-se a situação, descrita anteriormente como escandalosa. Será que isso ocorreu depois de os articulistas do Jornal $A$ Folha de Caxias, em contato com as normalistas, tomarem ciência que algumas delas já atuavam no ensino antes mesmo de terminarem o curso? Quanto às escolas particulares a exigência não seria tanta em relação a um concurso para admissão de professores(as), como deveria ser para as escolas públicas. Enfim, não se questionava a qualidade do Curso Normal anexo ao Ginásio Santo Antonio, interessava apenas que este formaria as primeiras professoras e por ser uma escola dirigida por Irmãs Franciscanas, só isso já era o suficiente para demonstrar sua idoneidade, seriedade e qualidade do ensino promovido.

Esta espécie de "positividade" e esperança, aliada a uma dúvida e cobrança em relação às(aos) professoras(es) de Duque de Caxias, mais especificamente, passa a ser a tônica dos articulistas às vésperas da formatura da primeira turma de normalistas para a cidade e região. Por ocasião de um concurso para admissão de um despachante municipal, foi encontrada a seguinte nota:

O Boletim Oficial de 27 de novembro do corrente ano, publica um ato do Exmo Sr. Prefeito designando a comissão que deverá examinar os candidatos inscritos no concurso de Despachante Municipal.

A escolha recaiu num despachante, como determina a Deliberação 75 , de agôsto de 1949 e mais no procurador da Municipalidade e no atual chefe do Serviço de Contabilidade. Reconhecemos a competência dos membros escolhidos, porém o que estranhamos, em se tratando de uma prova de verificação de capacidade, é a ausência de um professor, pois segundo me parece, esta é a função verdadeira do professor - examinar a capacidade de qualquer cidadão, candidato a qualquer cargo. Temos a impressão de que o Exmo Sr. Prefeito não confia na capacidade cultural dos atuais professores Municipais, tendo em vista a maneira leviana com que sua Senhoria nomeia professores para os quadros Municipais, embora possamos ressalvar pouquíssimas e honrosas exceções.

Aí fica registrada a pouca consideração que o Exmo. Sr. Prefeito tem pela nobre classe dos professores que militam nessa terra do Duque de Caxias (O Prefeito reconhece a incompetência do Magisterio Municipal. O Municipal, Duque de Caxias, Ano IV, n.109, 20 dez. 1955, p.04).

Repara-se que todos os atos do prefeito passavam a ser vistos por uma lente de desconfiança, ao tomar o prefessorado como ponto de referência. Critica-se a prática da nomeação de professores para o município, o que segundo o articulista, faz com que nem mesmo o próprio prefeito confie naqueles a quem nomeou, quando se considera a falta de critérios para tal. De qualquer forma, chamava a atenção para o fato de que o então prefeito reconhecia a incompetência do magistério municipal; e chamava a atenção para a necessidade de mudanças nos critérios de contratação dos docentes que atuariam nas escolas municipais. É fato que o autor (anônimo) da nota no jornal, não generaliza o quadro docente como totalmente incompetente: há as exceções. Certamente não queria se comprometer.

Problemas relativos especialmente à demanda por docentes, bem como à qualidade de seu ensino, não diziam respeito apenas a um ou outro município, mas ao Estado do Rio de 
Janeiro de maneira geral. E na perspectiva do então secretário de educação do Estado, a falta de professores nos grupos escolares, em alguns municípios tinha a seguinte explicação:

As reclamações [...] originam-se do seguinte: $1^{\circ}$ - a não recondução, êste ano, das 'contratadas' 10 , com a admissão das quais despenderam os cofres públicos, em 1955, a apreciável soma de Cr\$9.000.000,00 (nove milhões de cruzeiros), sem que, com isso lucrasse o ensino; $2^{\circ}$ - o aumento do trabalho das regentes de classe, que passaram a lecionar a turmas de quarenta alunos, como a lei determina, quando, face à existência das 'contratadas' êsse trabalho se tornava mais suave; $3^{\circ}$ - o velho hábito, infelizmente ainda não erradicado do nosso sistema escolar, de se pedir professôra à vista da matrícula geral, quando esta, por ser uma coisa instantânea, não pode oferecer elemento nenhum de precisão; $4^{\circ}$ - vários atos de nomeação para escolas de zona rural, os quais foram tornados sem efeito porque as candidatas, logradas na pretensão de ficarem adidas aos estabelecimentos da cidade, declinaram do que obtiveram por concurso; $5^{\circ}$ - o sensacionalismo com que certas informações são levadas aos órgãos de opinião, de um lado e, de outro, o açodamento com que os veiculam indivíduos recalcados, sem que antes se proceda a uma verificação de causa e efeito. Entretanto, providências já estão sendo adotadas por esta Secretaria para que se atenda, em curto prazo, às necessidades reais do Ensino, de acordo com as diretrizes traçadas pelo sr. Governador, professor Miguel Couto Filho, ao titular da Pasta (Explica o Secretário de Educação do Estado o motivo da falta de professoras no Grupo. A Folha de Caxias, Duque de Caxias, Ano III, n.106, 16 abr. 1956, p.06).

O governo do Estado se defendia ao afirmar que mesmo com o contrato de novas professoras, o ensino não lucrou em 1955, ou seja, não melhorou. Nesse sentido, por que contratar mais professoras em 1956? Aí fica implícito também o debate entre a quantidade e a qualidade. A formação para as licenciaturas estava aquém do necessário; assim, por mais que se contratasse, não se sanaria o problema mais profundo da educação, que era o de conteúdo ou qualidade. Como novas professoras não foram contratadas, o trabalho das regentes, em salas de 40 alunos, ficou mais árduo, não havia quem as ajudasse. Em terceiro lugar, os grupos escolares só requeriam professores após encerradas as matrículas, o que não possibilitava que o governo de Estado tivesse uma noção precisa da quantidade necessária de professores(as). Em quarto lugar, os(as) concursados(as) não queriam ir para as escolas localizadas nas zonas mais periféricas, dando preferência a locais mais centrais, dessa forma, não acatavam a nomeação ou designação do governo para atuarem nesta ou naquela escola. $\mathrm{O}$ que seria resolvido futuramente, conforme artigo escrito por Lynx e transcrito mais à frente, em que, além de um aumento de salário para os(as) professores(as) do Estado, aqueles(as) que fossem escalados(as) para uma localidade subdesenvolvida receberiam gratificações ou incentivos. Em quinto e último lugar, o governador faz uma crítica aos órgãos de opinião, que eram impiedosos ao julgarem sem antes verificar as causas e os efeitos de suas suposições ou pronunciamentos.

O Grupo Escolar Duque de Caxias, único público estadual, na cidade de mesmo nome, sofria por falta de professores(as). Para se ter uma ideia, em 1956, de 1.100 alunos matriculados, 600 estavam sem vagas porque 20 docentes não foram nomeados(as) pelo Estado e os outros 500 alunos estavam sem vagas por não haverem salas de aula suficientes (1.100 alunos aguardam no Grupo a vinda de professoras do Estado. A Folha de Caxias, Duque de Caxias, Ano III, n.107, 22 e 23 abr., 1956, p.03). Mesmo assim os órgãos de opinião seriam "impiedosos" ao denunciarem a situação vexatória a que a educação local havia chegado? 
Ainda sobre a falta de professores, nas colunas 5 e 6 da "Folha de Caxias" de 22 e 23 abril de 1956, p.03, anteriormente referido, era anunciado que em Imbariê, $2^{\circ}$ distrito de Duque de Caxias, mais 197 (cento e noventa e sete) crianças esperavam por professores(as):

Para solucionar tal situação o vereador Leandro Gonçalves Maia, através da Mesa da Câmara Municipal, enviou oficio ao Secretário de Educação do Estado do Rio, solicitando que sejam enviadas para Caxias mais sete professôras (1.100 alunos aguardam no Grupo a vinda de professoras do Estado. A Folha de Caxias, Duque de Caxias, Ano III, n.107, 22 e 23 abr. 1956, p.03).

Para tal situação ${ }^{11}$ não existia uma solução fácil, resolvida com pouco custo; mesmo porque não se tratava apenas de uma escola ou grupo escolar em específico. Resumidamente encontrava-se assim a situação no mínimo de Duque de Caxias nesse setor:

A situação precária da nossa instrução pública de há muito vem sendo criticada, tal o estado verdadeiramente caótico a que está reduzida.

Milhares de alunos matriculados estão à espera de professoras; êstes ainda são mais felizes do que aquêles que não lograram vagas não à custa sòmente de professoras - mas de escolas também.

Além da ausência de escolas e professoras, sabe-se ainda que o estado das primeiras não raro impede seu funcionamento, à falta do material, indispensável, em cujo rol se conta até mesmo conservação dos prédios e água.

O deputado Sá Rêgo, exemplo raro entre nós de político que não se lembra do povo apenas às vésperas das eleições, reclamou recentemente, da tribuna da Assembléia fluminense, as providências necessárias.

Fez ver que Duque de Caxias não era sòmente no Estado do Rio um dos municípios mais prósperos e portanto que a grande renda proporciona ao erário estadual. Mas que também é considerado, em escala muito maior, dos principais núcleos populacionais da Velha Província, merecendo destarte mais cuidados por parte do governo. [...] (LYNX. Problemas Caxienses Educação. A Folha de Caxias, Duque de Caxias, Ano III, n.110, 14 mai. 1956, p.04).

É possível perceber através destes artigos de denúncia quanto à falta de professores(as), um movimento insistente a favor da contratação - seja através de concurso ou mesmo de nomeação - das normalistas, necessariamente aquelas prestes a se formar no Curso Normal anexo ao então Ginásio Santo Antônio, dirigido pelas Irmãs Franciscanas de Dillingen. Isto ficou claro em artigo do dia 20 de maio de 1956, escrito por Lynx:

Sempre julgamos, de um modo geral, agirem por mero idealismo as jovens que buscam se tornarem professôras. Profissão árdua, especiosa, mesmo nos centros mais adiantados proporciona remuneração inferior a muitas outras que demanda menos estudo, menos dispêndio de tempo e talvez de despesa também menor.

Mas aqui em Caxias o panorama é muito mais triste. O idealismo das moças chega às raias do sacrifício, do desprendimento, da renúncia total a quanto represente estabilidade futura, desde que não se apresenta às mesmas a certeza de que terão garantido o seu direito de exercício à espécie de trabalho que escolheram. 
Explicamo-nos. Foi criado há anos atrás um curso normal para formação de professôras. A primeira turma forma-se êste ano.

Existindo já um curso dessa espécie, lògicamente essas moças deveriam ter todo o apôio da Prefeitura, que se obrigaria, prestigiando e incentivando não apenas as futuras normalistas, porém mesmo as vocações existentes em muitas outras jovens, - repetimos — deveria obrigar-se a ir nomeando para as vagas surgidas alunas da Escola Normal.

Entretanto estas são postergadas em seus direitos, pois, em detrimento a tais direitos, senão reais pelo menos implícitos — são preteridas por "professôras" leigas. (grifamos a palavra "professôra" porque a quase totalidade destas, as leigas, sòmente ganharão o título específico após a nomeação).

Essa é a verdade cruel.

Agora note-se o que representaria, em ajuda material, a nomeação dessas moças, que tantos anos empatam no curso normal: iriam ter um ordenado de Cr\$1.080,00 — quase o igual pago a uma empregada doméstica.

Não queremos, em absoluto, parecer às professôras [...] que subestimamos seu valor ou somos inimigos das mesmas.

Nunca. Tivemos prova, por experiência pessoal, que existe entre as professôras leigas, figuras exponenciais de educadoras provectas. Que se não tiveram sua educação pedagógica no currículo das escolas, fora delas ilustraram-se suficientemente para desempenhar seu nobre mister com eficiência.

A nomeação de professôras leigas dêste quilate é obra de justiça. Infelizmente - e as Mestras eficientes e honestas hão de reconhecer conosco - nem sempre êste é o caso.

Outro fato que se enquadra neste assunto e merece comentário é o recente e substancial aumento concedido às professôras estaduais. Passarão a ganhar $\mathrm{Cr} \$ 4$ mil, afora gratificações e ajudas especiais às que forem escaladas para localidades subdesenvolvidas e que possa representar thes demasiado sacrifício.

Cumpre portanto às nossas autoridades reajustarem os proventos das professôras municipais - quando menos para atenuar a diferença que virá a se estabelecer entre os dois padrões.

Confiamos também, como sempre, numa mudança de atitudes da Prefeitura em relação às nossas futuras normalistas. Afinal, o fim do ano vem aí, essas moças vão se formar - e necessitam de trabalho (LYNX. Problemas Caxienses - Professôras. A Folha de Caxias, Duque de Caxias, Ano III, n.111, 20 mai. 1956, p.04).

Virava e mexia o Curso Normal que formaria sua primeira turma em Caxias, no final de 1956, era trazido à tona. E neste artigo outro problema é retomado: a questão salarial. Equiparado ao salário de uma empregada doméstica o ordenado de um professor municipal, também seria menos que a metade do ordenado de um professor estadual, o que sem dúvida gerava questionamentos e disputas, conforme adiantado por Lynx. Mais uma vez também a questão das professoras leigas é trazida para o debate. As "moças" que cursavam o Normal ganhariam o título de professoras assim que terminassem o Curso, mas as leigas, que então ocupavam a quase totalidade dos cargos docentes, recebiam o mesmo título simplesmente ao serem nomeadas. Nesse sentido, o autor cobra um diferencial para o produto do Curso Normal em detrimento daqueles(as) que não passaram pelo mesmo.

A pressão que a imprensa escrita fazia junto ao poder público era constante. Uma hora chamava a atenção para os salários atrasados ou baixos, outra hora para a falta de critérios em 
admitir professores(as), geralmente leigos(as), outra hora ainda, dada a falta de professores(as), para que se pensasse numa forma de contratar as normalistas que se formariam pela Escola Normal, anexa ao então Ginásio Santo Antonio, em Duque de Caxias.

A reportagem da FOLHA DA CIDADE abordou as estudantes da $3^{\mathrm{a}}$ turma do curso Normal da Escola Normal de Santo Antonio, à saída da aula, têrçafeira última, no páteo fronteiro à escola. Nossa intenção era fazer uma rápida enquete com as futuras professôras de Caxias, sobre os seus planos quando deixarem os bancos escolares com o diploma de professoras. As jovens normalistas concordam imediatamente em responder as perguntas do repórter.

NOMEAÇÃO

"Queremos uma escola para lecionar". Disse Eny, em nome das colegas, enquanto outras acrescentaram: "Mas só aceitamos nomeações da Prefeitura Municipal se o ordenado fôr equiparado ao do Estado do Rio".

A preocupação das normalistas é terem assegurado um local para lecionar com um ordenado justo. (Queremos uma escola para lecionar. Folha da cidade, Duque de Caxias, Ano I, n.8, 20 ago. 1956, p.1 e 2).

Aqui é possível perceber o poder de circulação das notícias veiculadas pela Folha da Cidade (outrora A Folha de Caxias), já que em artigo publicado por Lynx em 20 de maio do mesmo ano (transcrito anteriormente), o articulista já anunciava o aumento salarial que as professoras estaduais obteriam. Nota-se igualmente uma autoconfiança muito grande por parte das então normalistas, se forem consideradas as suas exigências, sabedoras do diferencial de sua formação e das pressões sofridas pelas professoras leigas através da imprensa.

\section{Entre uma e outra Formatura de Normalistas em Duque de Caxias}

Finalmente chega o momento da formatura das primeiras professoras em Caxias. No dia 15 de dezembro de 1956, às 9 horas da manhã houve uma festa de despedida no pátio da escola; no dia 16, às 18 horas, houve a missa em ação de graças na Igreja Matriz de Santo Antônio e às 20 horas do mesmo dia a solenidade de colação de grau no salão nobre da Escola Normal Santo Antonio. Eram em número de 18 (dezoito) as novas professoras:

Anna Maria Baptista, Carmen Martins de Carvalho, Elecy Cunha da Costa, Ely José Donato, Eni Hassel de Souza, Ermelinda Barcello Garcia, Gercy Martins Bastos, Graziela das Neves, Jorcelina Alves de Amorim, Laura do Carmo Soares, Lazara Ferraz de Campos, Maria Nancy Almada, Maria Robertina Cardoso Gomes, Maryse Cardoso Gomes, Myrian Cardoso Coutinho, Therezinha de Albuquerque, Enice da Silva, Yvonette Nunes Alverca.

A oradora da turma é a professoranda Maria Nancy Almada e o Paraninfo o professor Affro do Amaral Fontoura, emérito sociólogo fluminense (As primeiras professoras formadas em Caxias... Folha da Cidade, Duque de Caxias, Ano I, n.22, 26 nov. 1956, p.02).

[...] Ás 20 horas, com a presença do Exmo. e Revmo. Sr. Bispo da Diocese de Petrópolis, D. Manoel Pedro Cintra, do Vigário da Paróquia de Santo Antônio, Frei Joaquim Orthi OFM, [...] teve início a solenidade de colação de gráu das novas professôras, com o Hino Nacional cantado pelas diplomadas. Em seguida foi feita a entrega dos diplomas às professorandas. 
Depois de um número de música, executado ao piano por uma professoranda e ao Violino por uma aluna do curso Ginasial, a oradora da turma, Srta. Maria Nanci Almada, fez um bonito discurso de despedida, que emocionou, não só suas colegas como a todos os presentes.

A seguir falou D. Manoel Pedro, Bispo de Petrópolis, dando a sua benção às novas professôras.

Por fim o prof. Amaral Fontoura, eminente professor de sociologia e Diretor da Divisão do Ensino Médio do Estado do Rio de Janeiro, como paraninfo da turma, fez-se ouvir numa magnífica peça oratória, saudando as suas afilhadas, sendo vivamente aplaudido pela assistência, que cativou com sua simplicidade e facilidade de expressão (Diplomada a primeira turma de professoras formadas em Caxias. Folha da Cidade, Duque de Caxias, Ano I, n.26, 24 dez. 1956, p.01 e 10).

O paraninfo da primeira turma foi autor de pelo menos 3 (três) manuais pedagógicos: Fundamentos de educação (princípios psicológicos e sociais, elementos de didática e administração escolar) - 1948; Metodologia do ensino primário (que continha a matéria dos $2^{\circ}$ e $3^{\circ}$ anos do Curso Normal) - 1955; e Didática Geral - 1969. (SILVA, 2003, pp.29-58). É notório que os dois primeiros livros de sua autoria foram publicados numa época contemporânea ao processo de formação da $1^{a}$ turma do Curso Normal, o que é demonstrativo de que as Irmãs Franciscanas de Dillingen acompanhavam de perto as inovações pedagógicas propostas naquele momento.

Ao se retomar a questão da educação em Duque de Caxias, passada agora a formatura das primeiras professoras do município e região, as críticas ao governo municipal continuam:

[...] Não chega o prefeito Francisco Corrêa ao cúmulo de declarar-se, pùblicamente, contrário à educação, ao ensino primário, como fez o seu antecessor, sr. Braulino Reis, salientando ostensiva e orgulhosamente a sua ignorância, ao dizer a uma professôra desta cidade considerar desnecessária a criação de novas escolas, pois êle (que exemplo!), nem sequer completou o curso primário, mas, chegou a Prefeito desta terra. O sr. Francisco Corrêa demonstra um certo interêsse pela instrução pública, criando, periòdicamente, novas escolas, novos educandários mantidos pela Municipalidade.

Muito bem! Criar escolas é obra merecedora de aplausos. Mas, e daí? Que mais fez o Prefeito de Duque de Caxias? Nomeou professôras. Nomeou-as, simplesmente, sem concurso, sem um exame meticuloso e indispensável da capacidade cultural e funcional das nomeadas. [...] O essencial é saber a quem entregar essas escolas, é formar Escolas, dentro dos modernos princípios que regulam a educação. Que se pode esperar de uma infância educada e instruída por "mestras" sabidamente incapazes, que nada entendem de pedagogia, de metodologia do ensino, de psicologia infantil? Se duvidam, procurem submeter as professôras primárias de Duque de Caxias, a um rigoroso exame. Garantimos que, pelo menos $50 \%$ não resistiria à prova. Não queremos melindrar ninguém e conhecemos muitas professôras capazes, porém, auscultem os alunos das nossas escolas. Êles atestarão a veracidade do que afirmamos.

O desinteresse da Administração Pública pela educação da infância, pela preparação do caráter e personalidade daqueles que serão a garantia do futuro do Município e do País, é mais que evidente, dadas as demonstrações cabais que o Governo Municipal nos tem dado neste particular. Em dezembro último, para citar um exemplo recente e importante, diplomaram-se as primeiras professôras formadas pela única Escola Normal do Município. Foi 
a primeira turma de educadoras do MUNICÍPIO. Para as solenidades foram convidadas as autoridades municipais. Não compareceram. Nem deram a mínima satisfação, enquanto que o Governador do Estado enviava, por telegrama, sua saudação às novas professôras.

As dezoito novas professôras formadas em Caxias, vão agora fazer concurso para Carreira Inicial pelo Estado. O Município não as quis aproveitar, nem mesmo através de um concurso! Isto dispensa comentários. Só lamentamos que o sr. Francisco Corrêa esteja empenhado em apenas construir escolas e não também em formar ESCOLAS! (BATISTA, Plínio. Professoras Municipais. Folha da Cidade, Duque de Caxias, Ano I, n.29, 14 jan. 1957, p.03).

Como se vê, as críticas agora não diziam respeito à quantidade de escolas, mas à sua qualidade, mais especificamente à qualidade do seu corpo docente. E nesse sentido, continuava a pressão pela contratação - seja por nomeação ou por concurso - das professoras formadas na única Escola Normal da cidade e região. O que Plínio Batista queria dizer é que era muito fácil criar escolas (geralmente compostas de uma ou duas salas como já ficou provado), mas o difícil era dotá-las com professoras, senão de qualidade, pelo menos aquelas "formadas", ou seja, que tivessem aprendido o mínimo de fundamentos da educação, métodos e técnicas de ensino e aprendizagem. Dessa forma, se não tinham o apoio da prefeitura de sua cidade, o tinham por parte do governo do Estado do Rio de Janeiro, cujo governador enviou ao menos um telegrama de saudação às novas professoras. $\mathrm{O}$ articulista certamente ressentiu-se com a Prefeitura Municipal, por seus representantes não terem prestigiado o referido acontecimento que para ele foi tão importante. Resta saber se o prefeito e seus representantes sentiram-se talvez encurralados pelas pressões sofridas e optaram por se ausentar do evento.

De qualquer maneira, parece que a Prefeitura começava aos poucos a ceder às pressões:

Dia 7 e 8 do corrente, realizaram-se, no Ginásio Municipal, as provas do concurso para ingresso no magistério municipal. A Prefeitura Municipal resolveu só admitir, de agora por diante, professôras mensalistas, mediante concurso, não mais havendo mestras contratadas. Cerca de noventa candidatas participaram das provas nesta semana. A maioria delas já eram professôras contratadas. Se aprovadas no concurso passarão a mensalistas. Também se inscreveram várias candidatas de outros municípios.

[...] Nossa reportagem apurou que vários vereadores têm procurado o prefeito Francisco Corrêa para tentar impedir a submissão de suas afilhadas ao concurso moralizador ora instituído. No entanto, até agora, nada conseguiram. Não só o Prefeito como o Dr. Raymundo Milagres, Chefe de Gabinete, fizeram "pé firme" e não cederam.

As candidatas reprovadas não serão aproveitadas. Apuramos que as provas serão corrigidas com o máximo rigor (Realizado o concurso para professoras municipais. Folha da Cidade, Duque de Caxias, Ano I, n.37, 08 mar. 1957, p.01).

Se o prefeito não podia promover um concurso para contratar novas professoras, este foi feito para legalizar a situação de algumas que já atuavam no magistério municipal enquanto "contratadas", que passariam a "mensalistas". O Concurso parecia realmente ser moralizador. O que já era alguma coisa. Repare que se o articulista afirma que várias candidatas de outros municípios se inscreveram, possivelmente seja porque as mesmas já trabalhavam para o município de Duque de Caxias, vindas de outras cidades. Lembrando que a proximidade e 
interelação entre as cidades da região da Baixada Fluminense é muito grande, o que justifica tal informação. Complementa-se agora com notícias a respeito de um concurso a nível estadual:

Dez das professôras recém-formadas pela Escola Normal Santo Antônio, desta cidade, inscreveram-se no Concurso de Ingresso no Magistério Fluminense, sendo classificadas com mais de novecentas (900) candidatas das milhares que participaram do concurso. Sábado, dia 23 de fevereiro, foi realizada a escolha de vagas (pouco mais de 400) e escolas pelas candidatas classificadas. Entretanto, as candidatas dêste Município não conseguiram, nenhuma delas, vaga em escolas de Duque de Caxias. Outras candidatas, como de Niterói, Nilópolis, etc., foram nomeadas para Caxias. [...]

Por não haverem vagas nem sequer nos municípios vizinhos a Duque de Caxias, apenas quatro das candidatas caxienses escolheram escolas, tôdas elas em Mangaratiba, no litoral fluminense. Duas delas residem em São João de Meriti, tendo estudado em Caxias. [...]

Fomos informados de que a Prefeitura Municipal pretende abrir, brevemente, concurso para professôras municipais, devendo, porém, antes, serem nomeadas as professôras recém formadas em Caxias, se assim o desejarem (Professoras de Caxias vão para Mangaratiba. Folha da Cidade, Duque de Caxias, Ano I, n.37, 08 mar. 1957, p.02).

Como se vê, das 10 normalistas que se inscreveram no concurso estadual, todas foram aprovadas. Isso prova que ou elas tiveram realmente uma boa formação ou uma formação que ia ao encontro dos anseios do Estado. Ao não conseguir vagas em escolas de Duque de Caxias ou limítrofes a esta cidade, apenas 04 das 10 aprovadas resolveram ir lecionar em Mangaratiba, RJ. Dessas 04, 02 residiam em São João de Meriti, apesar de terem estudado em Duque de Caxias $^{12}$, na Escola Normal Santo Antonio. O fato é que quem veio a conseguir vagas em escolas de Caxias foram candidatas oriundas de Niterói e Nilópolis, por exemplo. Tal situação demonstrava já a importância que tinha o transporte coletivo na região (trens e ônibus). Quanto à Prefeitura Municipal de Duque de Caxias, esta parece ter cedido às pressões da imprensa, no caso, quando assumia que mesmo antes de abrir concurso (o que faria brevemente) nomearia as professoras recém formadas que desejassem trabalhar no município. Não é possível acreditar que esta seria a melhor atitude da administração municipal, pois o justo mesmo seria, inclusive as normalistas, entrarem para o efetivo dos funcionários municipais através única e exclusivamente de concurso público de provas e títulos. No mínimo teriam que dar o exemplo. Concurso este que ocorreu realmente entre os dias 8 e 13 de março de 1957, visto pela imprensa como de grande valor, por mais que tenha havido falhas (Foto - Folha da Cidade, Duque de Caxias, Ano I, n.38, 13 mar. 1957, p.01).

No dia 18 de março de 1957, ganha destaque novamente na imprensa, a problemática da Educação em Duque de Caxias e no Estado do Rio de maneira geral:

A informação prestada ao jornal de cultura "Grupo", pelo Serviço de Estatística, de que 10 mil crianças estão sem escolas em Caxias, quando há 22 mil crianças em idade escolar, vem demonstrar a gravidade do problema do ensino no Município, já tantas vezes por nós comentado. A falta de escolas e de professôras é a causa fundamental do problema, que assume aspecto mais grave, quando verificamos ser Duque de Caxias o município de maior índice de crianças ameaçadas pelo analfabetismo no Estado do Rio.

Recentemente, referindo-se ao problema do ensino no Estado, o deputado Dail de Almeida falou na Assembléia, dizendo que cerca de 26 mil crianças fluminenses estavam impedidas de freqüentar escolas. Vê-se que, só o município de Duque de Caxias atinge quase metade dêsse número de 
crianças sem escolas. A promessa do governo do Estado de construir mais grupos escolares em Caxias, em terrenos já doados pela Municipalidade, se não é a solução definitiva, seria pelo menos um paliativo.

Por seu turno, o governo do Município, que destina uma verba ínfima para a educação e cultura, faz ainda um extôrno de 700 mil cruzeiros, dessa verba, para pagar regime de cotas, demonstrando assim pouco ou nenhum interêsse pelas dezenas de milhares de crianças que estão esperando escolas, onde possam instruir-se e educar-se.

Em Caxias, como em todo o Brasil, a educação pública é sempre relegada a plano secundário. (Educação e Cultura. Folha da Cidade, Duque de Caxias, Ano I, n.61, 18 mar. 1957, p.03).

O problema da Educação em Caxias que por muito tempo teve relação com a qualidade dos professores, neste artigo perpassa a quantidade, ou seja, a falta de escolas e de professores(as). E se das 26.000 crianças de Duque de Caxias 10.000 ficavam sem escolas, realmente estas estavam em falta naquele município, um dos maiores da Baixada Fluminense. Até 1957 existia ali apenas o Grupo Escolar Duque de Caxias, e o paliativo encontrado pelo Município e Estado seria a construção de mais 02 grupos, dentro de suas possibilidades. É evidente que havia muitas escolas municipais e particulares, confessionais ou não, mas na sua maioria funcionavam de forma precária.

Em sua mensagem dêste ano à Assembléia fluminense, o governador Miguel Couto Filho referiu-se às iniciativas do governo em pról da educação pública. (...)

Duque de Caxias é que não foi beneficiado com nada do Estado no terreno educacional. Diz-se que o governo fluminense, com relação a êste município, só se preocupa atualmente com o problema do abastecimento dágua. Necessitamos, porém de um Ginásio Estadual. Há outros problemas de educação pendentes da iniciativa governamental.

Centenas de alunos dos Grupos Escolares de Caxias estão sendo prejudicados por falta de professôras. Entretanto, no recente concurso de ingresso no Magistério Fluminense, foram dadas a escolher apenas dez vagas em tôdas as escolas do município. E nenhuma das professôras locais conseguiu nomeação para Duque de Caxias. Coisa que não têm explicação... (Educação e Cultura - Educação Fluminense. Folha da Cidade, Duque de Caxias, Ano I, n.39, 25 mar. 1957, p.04).

Em outro momento, se o problema da falta de água era prioridade, agora já não é assim que o articulista vê. Mais uma vez o que contava era a qualidade, era zerar o número de professoras leigas ou incompetentes para o cargo, agora o que conta é que faltam professôras, não importa sua formação. Antes se "levava mais fé" no Estado que no Município de Caxias, por ocasião da formatura da $1^{\text {a }}$ turma de normalistas e da predisposição pelos concursos públicos; agora o Estado já não cumpre com suas promessas. Ao final o articulista lembrou que nenhuma das 10 normalistas formadas em Caxias conseguiu vaga para trabalhar em Caxias. Evidentemente que se não fosse dessa forma, não teria sido por concurso, ou este não seria confiável.

Vereadores e interessados estão exercendo verdadeira pressão junto ao Prefeito Francisco Corrêa, a fim de serem admitidas também, no quadro do magistério municipal, candidatas reprovadas, no recente concurso realizado. 
Cerca de 30\% das candidatas não conseguiram aprovação no concurso, estando entre estas muitas que já exerciam função de magistério como contratadas. Daí a pressão junto ao Prefeito [...]

Falando à nossa reportagem, a Inspetora Municipal do Ensino, D. Regina Tescaro Sampaio, declarou: Apenas cumpri com o meu dever. Já enviei os resultados das provas ao sr. Prefeito" [...]

Informou-nos D. Regina que as candidatas aprovadas não preencheram as vagas existentes. Assim, as vagas restantes serão preenchidas pelas professôras recém-formadas pela Escola Normal Santo Antônio. (Pressão política para serem admitidas as professoras reprovadas. Folha da Cidade, Duque de Caxias, Ano I, n.39, 25 mar. 1957, p.01).

Grande foi a pressão imposta pelos(as) que se achavam prejudicados(as) com o concurso promovido pela Prefeitura Municipal de Duque de Caxias. Ainda mais que as vagas não foram preenchidas apenas pelos(as) aprovados(as). Entretanto, conforme se entendeu, nem mesmo as professoras recém-formadas pela Escola Normal Santo Antônio passaram no concurso, ou será que elas não teriam se inscrito no mesmo? Como já afirmado anteriormente, para além de sua formação, assim como qualquer outra candidata ao cargo, as professoras recém-formadas também deveriam se submeter a uma avaliação de sua capacidade. Do contrário, se faria uso de dois pesos e duas medidas. Entretanto, deve-se considerar o contexto, bem como a demanda por professores(as) com ou sem qualificação. Ou seja, a opção por nomear ou admitir as professoras recém-formadas da Escola Normal Santo Antonio, ao invés de qualquer outra professora leiga, seria naquele momento a atitude mais acertada.

Quando discursava como patrono da primeira turma de professôras formadas em Caxias, o prof. Amaral Fontoura afirmou ser um ato de heroísmo dedicar-se ao ensino no Estado do Rio. Realmente, sob todos os aspectos, o professor fluminense é um herói. São inúmeras as dificuldades que tem de enfrentar no seu mister de educar e de ensinar. O pior é que são mal remuneradas as professôras fluminenses

O governador Miguel Couto Filho prometeu, várias vezes, elevar o nível salarial das educadoras fluminenses. Entretanto, já foram aprovadas pelo próprio governador as minutas do contrato a ser assinado entre a Secretaria de Educação e 23 professôras rurais, com o pequeno salário de $\operatorname{Cr} \$ 3.500,00$, ou seja, nível igual ao de salário mínimo vigente no Estado do Rio.

Em Duque de Caxias, as professôras são também muito mal remuneradas. Com a recente reestruturação do funcionalismo municipal, houve, realmente, melhoria do nível salarial das professôras municipais. Mas, não corresponde ao sacrifício de quem dedica todo o seu esforço ao ideal de educar e instruir a infância. E nem atinge às necessidades do atual custo de vida, pois, o salário das educadoras da Prefeitura é bem inferior ao salário mínimo em vigor. E, parece, nunca haverá tanto no Estado como no município, um reajustamento que corresponda à justiça (Educação e Cultura - Sempre Mal Remuneradas. Folha da Cidade, Duque de Caxias, Ano I, n.40, 31 mar. 1957, p.04).

A problemática da remuneração do professor torna à cena. Se o Governo do Estado fluminense propunha um aumento para as professoras do meio rural que se equipararia ao salário mínimo, é porque as mesmas ganhavam menos que este até então. Quanto às professoras urbanas, presume-se que ganhavam um pouco mais que o salário mínimo, isso no Estado. No entanto, mais especificamente as que recebiam da Prefeitura Municipal de Duque de Caxias estas sim, ganhariam menos que o mínimo em vigor na época, em proximidade com 
o salário das professoras do meio rural. Junte-se a isto o custo de vida e é possível presumir as dificuldades pelas quais passava esta categoria profissional.

Ainda em 31 de março de 1957 saiu a seguinte nota:

Atendendo a uma sugestão dêste jornal, o deputado estadual Antônio Carlos Sá Rêgo, falou da tribuna da Assembléia Legislativa do Estado do Rio, sôbre a necessidade de o Governo do Estado cumprir a sua promessa de construir, neste municipio, mais dois grupos escolares. Para tal já existem terrenos destinados.

O atual Grupo Escolar Duque de Caxias, o único da cidade, já não comporta a grande afluência de alunos, principalmente por falta de professôras. Segundo fomos informados, faltam no Grupo Escolar quinze professôras. Por êste motivo, como ocorreu no ano passado, cerca de mil alunos ficaram sem matrícula (Sá Rêgo pediu na Assembléia a construção. Folha da Cidade, Duque de Caxias, Ano I, n.40, 31 mar. 1957, p.01).

Do que adiantava querer abrir mais dois Grupos, se no que existia faltavam 15 (quinze) professoras? Certamente faltavam salas de aula também, visto que cerca de mil alunos ficaram sem se matricular. Isso justifica a necessidade de abertura de outras instituições escolares públicas. É importante ficar claro que até aquele momento (1957) existia na cidade de Duque de Caxias apenas um Grupo escolar, de caráter público; o que, de uma ou outra forma, justifica a instalação e presença das muitas escolas particulares ali, dentre elas o atual Colégio Santo Antônio fundado no início da década de 1940. Em abril o problema da falta de professoras continua a ser veiculado pela imprensa:

O deputado Dail de Almeida fez através da tribuna da Assembléia fluminense, um apelo ao governador Miguel Couto Filho, para que sejam criadas, no Magistério do Estado do Rio, mais duzentas e cinquienta vagas para professôras. Disse o parlamentar que milhares de crianças, em todos os municípios fluminenses, estão impedidas de estudar, por falta de professôras. No ano passado foram criados mais 500 cargos, mas, neste ano, sòmente em São Gonçalo, ficaram sem estudar mais de seis mil crianças. Outros deputados também se referiram ao problema, citando municípios como Petrópolis, Itaperuna e Campos. Em Duque de Caxias, também milhares de crianças ficaram sem matrículas no Grupo Escolar por falta de mestras. (Educação e Cultura - Notícias - Mais 250 Professôras. Folha da Cidade, Duque de Caxias, Ano I, n.41, 07 abr. 1957, p.04).

Assim percebemos que não era apenas em Duque de Caxias que faltavam professores(as), nem só em outros municípios da Baixada Fluminense. Em geral o Estado do Rio pedia socorro, pois o número de crianças sem escolas, por falta de docentes, era realmente muito grande. Deve-se considerar que o aumento da população, - devido aos movimentos migratórios principalmente, em função do crescimento do número de empregos - colaborou para o aumento dessa demanda, pois se o Estado criara 500 cargos em 1956 e logo no ano seguinte ainda faltavam professores em grande quantidade é porque realmente a população aumentava desmesuradamente.

No geral, ainda quanto à qualidade do ensino, em 12 de maio de 1957 foi publicada uma nota sobre as possíveis causas da deficiência do ensino ou sobre a má qualidade do ensino no Brasil. Para o professor Clóvis Salgado, então Ministro da Educação e Saúde, a causa principal da decadência do ensino era a deficiência dos professores. Mas segundo o articulista, o problema era de ordem muito mais ampla, não restrito apenas à formação de mestres 
eficientes. Se o problema fosse apenas o que o Ministro havia apontado, se poderia jogar a responsabilidade naqueles que formavam os professores, ou seja, nas Faculdades de Filosofia e até no Ministério da Educação; isso sem falar nas Escolas Normais. As declarações de dois professores na época a esse respeito foram transcritas do jornal "O Globo". Respectivamente, os professores Thompson Flores e Menezes Pimentel:

— [...] As causas são múltiplas e não podem ser atribuídas sòmente aos professores, tanto mais que nas principais cidades do Brasil existem Faculdades de Filosofia que fornecem professores de alto nível. Acredito que no interior haja relativa deficiência por falta de professores com a devida formação didática. Muito mais justo seria atribuir a deficiência no preparo à Lei Orgânica do Ensino, que precisa ser urgentemente modificada. Acredito, que aprovado o projeto, ora em curso no Senado Federal, haverá sensível melhoria no ensino atual.

- O Ministro não pode apontar o problema como derivante da falta de preparação dos mestres, pelas seguintes causas: 1) o grande número de disciplinas; 2) os alunos não preparam mais suas aulas nos estabelecimentos de ensino, como ocorria antigamente; 3) vencimentos de professor - o padrão de vida, muito elevado, faz com que êle dê muitas aulas, ficando extenuado. [...] (Educação e Cultura - A Deficiência no Ensino. Folha da Cidade, Duque de Caxias, Ano I, n.46, 12 mai., 1957, p.04).

Segundo o articulista, o Ministro Clóvis Salgado precisava estudar melhor os problemas relativos à educação, no sentido de apontar para possíveis soluções. Deve-se lembrar que a Lei de Diretrizes e Bases da Educação seria promulgada em 1961, ou seja, quatro anos após tais declarações. Quanto ao segundo depoimento, é possível afirmar que pouco ou quase nada tenha se alterado de lá para cá: Excesso de disciplinas, falta de interesse dos alunos e baixos salários dos professores; estas sim seriam as causas para a má qualidade do ensino; mas por que não, também, o despreparo dos professores?

Estava previsto para o dia 11 de janeiro de 1958 um concurso para o Magistério primário no Estado do Rio de Janeiro. Voltado para normalistas, a prova escrita constaria de três partes: Metodologia das disciplinas do ensino primário; Psicologia da aprendizagem e Práticas escolares.

A escolha das escolas far-se-á a 15 de fevereiro, no ginásio Caio Martins, em Niterói, antecipadamente será publicada a relação das vagas existentes.

O preenchimento das vagas será feito de acordo com a classificação das candidatas; no caso de igualdade terá prioridade a candidata residente no município da escola. (Educação e Cultura - Normalistas farão em Janeiro concurso de ingresso. Folha da Cidade, Duque de Caxias, Ano II, n.75, 01 dez. 1957, p.02).

Interessante que, diferentemente dos concursos municipais, o Estado preocupava-se com o local de residência da candidata que viesse a requerer uma vaga, quando ocorresse empate; priorizava-se sua classificação, claro. Também ficou evidente que o número de vagas não foi publicado no edital do concurso, só depois de feitas as provas é que as(os) candidatas(os) tomariam conhecimento de tais dados.

Vive a Secretaria de Educação e Cultura do Estado a época mais atribulada do ano, neste período. Mil professorinhas, com tremenda algazarra e bom humor procuram legalizar, junto às repartições públicas, os papéis necessários para a inscrição no Concurso de Ingresso no Magistério 
Primário. A Diretora de Provimento de Cargos, a boa professôra Dórica Valle, procura atender a tôdas com a mesma urbanidade, apesar dos pedidos dos pistolões.

As candidatas são, aproximadamente, em número de mil, sendo que as vagas para as efetivas sobem apenas à casa das 200 , o que é muito pouco. Há outras duzentas vagas para as interinas, que, infelizmente, são distribuídas àquelas que têm bons pistolões. É, sem dúvida, uma maneira nem sempre honesta de se preencher vagas no magistério.

Mas o que realmente é necessário - e isto ninguém pode contestar - é a criação de escolas para estas professôras, [...]. (Educação e Cultura - As candidatas e as vagas. Folha da Cidade, Duque de Caxias, Ano II, n.80, 05 jan. 1958, p.04).

Muito concorrido o Concurso de Ingresso no Magistério Primário do Estado. Mil cento e vinte candidatas lutam pelas 200 vagas de efetivas e 200 de interinas. Os políticos começam a mexer com os "pauzinhos". É uma pena não haver decência nos concursos públicos; é uma pena o mérito ser suplantado pelo pistolão!... Mas isto é a realidade brasileira! (Educação e Cultura - Uma saída política. Folha da Cidade, Duque de Caxias, Ano II, n.81, 12 jan. 1958, p.04).

Na próxima semana, dia 14 precisamente, as normalistas fluminenses que prestaram o concurso de ingresso ao Magistério estadual, vão disputar no estádio Caio Martins a ultima batalha na escolha de sua escola.

Infelizmente, êste ano, não usaram o processo de utilização dos atestados de residência. Isto fez crescer o número de pistolões - deputados e prefeitos que juntam-se às normalistas para melhor sorte.

Muitas sairão alegres, conseguindo o fim almejado. A grande maioria, no entanto, sofrerá a grande decepção de não poder escolher escola...

As que conseguem escolas, também nem sempre são favorecidas, pois vêemse na contingência de ainda sem um amadurecimento completo, afastarem-se de seus familiares, para lutar pelo sagrado direito de ensinar a milhares de crianças, sem o sempre desejado e necessário contato com suas famílias. (Educação e Cultura - A Última Batalha. Folha da Cidade, Duque de Caxias, Ano II, n.84, 02 fev. 1958, p.02).

Finalmente foram preenchidas as vagas do magistério primário do Estado. A luta foi enorme e o critério adotado nem sempre justo.

Louvemos, no entanto, o espírito de justiça da professôra Dórica Valle de Oliveira, chefe da Divisão de Provimento de Cargos, que, como educadora exemplar, soube conduzir, dignamente, o concurso de ingresso. (Educação e Cultura - Agora ao Trabalho. Folha da Cidade, Duque de Caxias, Ano II, n.86, 16 fev. 1958, p.05)

Pela reportagem fica clara a discrepância entre oferta e procura por cargos de professora no rio de janeiro: Aproximadamente 1.000 candidatas fizeram a inscrição para o concurso em que eram oferecidas 200 vagas efetivas mais 200 interinas, ou seja, apenas 400 vagas no Estado. De qualquer forma, como se vê, por mais que se contratassem professoras(es) parece que o número de escolas ou salas de aula seria insuficiente para recebê-las.

O governador Miguel Couto Filho acaba de criar cinco ginásios estaduais para serem distribuídos pelos diversos municípios do nosso Estado. Se olharmos a medida sem estudá-la e sem penetrar no problema poderemos 
crer que é uma medida saneadora e que vem resolver os problemas do ensino em nossa terra. No entanto, não é esta a verdade. Pelo contrário, acreditamos que a medida do governo estadual tem interesses políticos de grande profundidade, já que o mesmo dá guarida e cobertura à Campanha Nacional de Educandários Gratuitos, seção do Estado do Rio, que é, indiscutivelmente, um instrumento político. Nós nos interessamos pelos ginásios estaduais, iremos lutar para que Caxias seja beneficiado com um desses ginásios, mas não podemos deixar de criticar o ato do governo que, menosprezando o ensino, deixando de resolver os inúmeros problemas que êle apresenta, como construção de escolas, grupos, escolas rurais e normais etc., atém-se a problemas de segunda ordem. Parece-nos que o governador quer chegar ao telhado antes de construir os alicerces.

Se o curso primário é um problema insolvente até os nossos dias, com milhares de professôras sem nomeação, milhares de crianças sem escolas, não tendo o Estado nem uma Escola Profissional, e ainda com enormes problemas pendentes de solução no setor da Educação, como pode pensar em solucionar os problemas do curso secundário.

Não, senhor Governador. Êste não é o caminho certo. O certo seria V. Excia. criar primeiro escolas e grupos para abrigar milhares de professôras normalistas e os "escolares" sem escolas. Depois sim, criaria escolas profissionais, alternando com a criação de ginásios.

Este seria o caminho certo, justo e que condiz com a nossa realidade, com as necessidades da nossa política educacional. $\mathrm{O}$ resto é demagogia, mas mesmo demagogicamente, não esqueça de Caxias, que já tem 150 mil habitantes e precisa, sem falta, de mais um ginásio gratuito.

Um lembrete, sr. Governador: Caxias só tem um Grupo Escolar que está funcionando em três turnos. Porque não construir um novo Grupo ou novos Grupos, sr. Governador? (Educação e Cultura - Uma saída política. Folha da Cidade, Duque de Caxias, Ano II, n.81, 12 jan. 1958, p.04).

No trecho da Folha da Cidade de 1958, a referência a "milhares", tanto de professores que ficaram sem trabalho quanto de alunos que ficariam sem escolas, pareceu muito além do real. Principalmente ao se lembrar que houve apenas 1.120 normalistas que prestaram o último concurso estadual. Complementarmente ao trecho transcrito do dia 08 de dezembro, parece que o problema também era que, ao invés de se investir no ensino fundamental, básico, queriase investir no secundário. E como se vê, Duque de Caxias, continuava em 1958 com apenas um Grupo Escolar (público, estadual), o que certamente abria margem para a criação e manutenção de escolas particulares.

Na semana passada, o governador do Estado, além de criar cinco ginásios estaduais, assinou ato criando a Escola Normal do Estado em Itaperuna, onde já existe um Ginásio do Estado. Sem dúvida, esta medida é digna de aplausos, já que vem beneficiar um rico município do Norte Fluminense. Acreditamos que o Governador venha a recompensar agora os municípios da Baixada, que teima em não reconhecer como grandes centros, como é o caso de Caxias.

Sr. Governador, falta dezenas de escolas em Caxias, São João de Meriti, Nova Iguaçu, Nilópolis, etc.! (Educação e Cultura - Uma saída política. Folha da Cidade, Duque de Caxias, Ano II, n.81, 12 jan. 1958, p.04).

Em atendimento à Baixada Fluminense havia a Escola Normal Santo Antonio, instalada em Duque de Caxias, particular e confessional. Inclusive, ainda no dia 08 de dezembro saía mais uma nota sobre a formatura de outra turma de normalistas: 
Realizam-se hoje as solenidades de formatura das professorandas de 1957 da Escola Normal anexa ao Ginásio Santo Antonio. Às 17 horas, será rezada missa em ação de graças na Matriz Santo Antônio. Em seguida, no salão nobre da Escola, a cerimônia da colação de grau, com o juramento solene das novas professoras formadas em Caxias.

Será patrono da turma o Exmo. Sr. Bispo de Petrópolis, Dr. Manuel Pedro da Cunha da Cintra e paraninfo o deputado federal Eurípedes Cardoso de Menezes. [...] (Educação e Cultura - Formatura de Professoras. Folha da Cidade, Duque de Caxias, Ano II, n.76, 08 dez. 1957, p.02).

É interessante lembrar que o paraninfo da primeira turma foi o professor Affro Amaral Fontoura e agora para a segunda, o referido deputado federal. As cerimônias de formatura continuavam atraindo figuras de destaque, na educação ou na política.

Volta a ser apontado o problema da "recomendação" por parte de pessoas influentes:

[...] A contribuição que a Prefeitura tem dado ao ensino primário é relativamente útil, pois, tem-se construído escolas, mas, no setor do professorado, o que tem valido é o pistolão político, não se tendo nenhum interêsse pela qualidade das mestras.

Os concursos não têm sido respeitados, as idéias daqueles que entendem da matéria são desrespeitadas e isto nos tem dado um ensino primário deficiente, e com poucas horas de aulas e professores sem capacidade intelectual, para o mister.

Agora, com as normalistas da Escola Normal Santo Antonio e com outras que aqui se tem fixado, esperamos uma grande melhoria, restando, apenas, que construam mais escolas, onde haja mais alegria para as crianças e mais tempo de aula e que se construa de uma vez a Escola Normal da Prefeitura. Pois só assim, poderemos ter um ensino primário eficiente (Educação e Cultura - Agora ao Trabalho. Folha da Cidade, Duque de Caxias, Ano II, n.86, 16 fev. 1958, p.05).

Parece finalmente que a Prefeitura de Duque de Caxias começava a construir escolas. Entretanto a concepção de escola deste articulista era a de espaço de alegria para as crianças, $o$ que denota certo idealismo. A reclamação a respeito da falta de qualificação dos professores continuava; e parece que por mais que a Escola Normal Santo Antonio colaborasse para sanar este problema, passava-se então a almejar uma Escola Normal desta vez municipal. Mais uma notícia:

A Secretaria de Educação e Cultura do Estado do Rio está propensa a criar, êste ano, novamente, os cargos de extranumerários, procurando suprir a deficiência do quadro de professôras primárias do Estado (Extra Numerários. Folha da Cidade, Duque de Caxias, Ano II, n.87, 23 fev. 1958, p.05).

Esta nota leva a pensar o seguinte: será que algum dia estes cargos deixaram de existir? O próprio Concurso promovido pelo Estado do Rio de Janeiro, sobre o qual se escreveu anteriormente, já apontava as 200 vagas para interinas, o mesmo que extra-numerárias. Nesse caso, seriam criadas mais vagas para além dessas 200 já existentes. Em maio isto se confirma e em junho muda tudo. Quem vai entender?

O Sr. Governador do Estado nomeou no dia 8 p.p. mais 60 professoras extranumerárias mensalistas, acreditamos que assim serão supridas as várias 
classes vagas existentes em vários municípios (Educação e Cultura. Folha da Cidade, Duque de Caxias, Ano II, n.98, 11 mai. 1958, p.03).

Em portaria dirigida ao diretor do Departamento de Educação Primária, o secretário de Educação do Estado do Rio recomendou suas providências junto aos chefes de Inspetorias Regionais para que promovam imediatamente a dispensa das professoras substitutas ou admitidas como extranumerárias ou contratadas (Educação e Cultura - Dispensa das professoras substitutas que passaram a extranumerárias ou contratadas. Folha da Cidade, Duque de Caxias, Ano II, n.102, 07 jun. 1958, p.06).

Antes disso, em março e abril de 1958, essa "contradança" das nomeações já se fazia presente, juntamente às cobranças ao Estado por parte do município de Duque de Caxias, seja quanto à falta de professores, seja quanto à falta de escolas ${ }^{13}$.

Posteriormente, sai uma nota sobre a criação de cargos no Estado, somente para Caxias seriam 24. Acredita-se assim, que as extranumerárias foram dispensadas, para se admitir no lugar delas, através de concurso, 24 professoras efetivas para Caxias. É bom lembrar que as extranumerárias dispensadas eram em número de 60.

O Sr. Governador tem sido prático nas nomeações de professoras, o que em verdade é muito bom. Lamentamos que a época seja pré-eleitoral, mas aceitamos de bom grado os 24 cargos criados para Caxias. Parabéns Sr. Governador. Muito obrigado deputado Sá Rêgo. Que mais professoras e escolas sejam criados em nosso estado, pois de luz é que precisamos (Educação e Cultura - Noticiário. Folha da Cidade, Duque de Caxias, Ano II, n.104, 22 jun. 1958, p.02).

Enfim, o Governo do Estado resolve finalmente criar 15 escolas primárias, que seriam instaladas em vários municípios, sendo apenas 2 para Duque de Caxias ${ }^{14}$, número este que seria insuficiente para a cidade.

Nossa reportagem ouviu, semana passada, dona Regina Sampaio, diretora da Inspetoria Municipal do Ensino e a Diretoria do Grupo Escolar do Estado. A primeira, muito reticente, disse-nos que, provavelmente, umas 5 mil crianças ficarão sem escolas, êste ano, mas que o Prefeito tudo tem feito para resolver tal problema.

D. Minervina, professôra do Estado, acredita que o Grupo deixará de receber uns 1.500 alunos (Educação e Cultura - Excedentes. Folha da Cidade, Duque de Caxias, Ano II, n.90, 16 mar. 1958, p.04).

O Sr. Miguel Couto, inseriu em sua mensagem à Assembléia e ao povo de nossa província, uma série de realizações. Com relação ao ensino, o Sr. Governador demonstrou ter gasto verbas bastante elevadas, construiu escolas, jardins de infância, grupos escolares, cooperou com as entidades particulares na construção de novas unidades escolares, aumentou as verbas para os ginásios particulares, criou novos ginásios, criou várias escolas agrícolas e técnicas, nos mais diversos Municípios do Estado, só esqueceu o Sr. Miguel Couto, do nosso querido Município, que já tem tantas mágoas dos governos anteriores que tanto prometeram a Caxias e nada deram. Agora é a vêz dêste Govêrno, que esqueceu que precisamos de escolas e muitas escolas, pois já somos uma população de 170 mil habitantes (Educação e 
Cultura. Folha da Cidade, Duque de Caxias, Ano II, n.91, 23 mar. 1958, p.04).

Informou-nos D. Minervina, diretora do Grupo Escolar (único no $1^{\circ}$ distrito), que uns mil a mil e quinhentos alunos ficariam sem escola êste ano. Êstes dados se referiam aos que lá tinham ido tentar matrícula. Agora chegam-nos outras informações: mais de 2.000 crianças ficaram sem escolas, isto porque a Secretaria de Educação ainda não nomeou as 8 professoras que o grupo está precisando. Ao mesmo tempo que outras atividades ocupam salas que poderiam ser usadas durante o dia (Educação e Cultura, Folha da Cidade, Duque de Caxias, Ano II, n.91, 23 mar. 1958, p.04).

Parece que Duque de Caxias, para além da falta de escolas e professores, passava também pelo problema do atraso dos vencimentos desses últimos:

[...] Em palestra com nossa reportagem, disseram-nos que só assim talvez tenham os seus ordenados pagos em dia, pois atualmente o atraso orça pela casa dos 4 meses.

Os professores de Caxias reuniram-se na última segunda-feira, no Club dos Quinhentos, [...]. O assunto prendia-se ao atraso dos vencimentos dos mestres que já não podem suportar mais o atual estado de coisas em que se encontram seus salários. [...] (Educação e Cultura. Folha da Cidade, Duque de Caxias, Ano II, n.105, 29 jun. 1958, p.06).

As professôras municipais estão atravessando uma fase muito difícil. É que com quatro meses de atrazo nos seus vencimentos (segundo várias delas nos informaram), estão sofrendo privações, já que muitas ganham para auxiliar o sustento dos lares. Ainda agora, com as festividades de 25 de agôsto, as nossas mestras, tendo de fazer várias despesas para se apresentarem na parada, foram pràticamente impedidas de fazê-lo (Atrazados quatro meses os vencimentos das professoras. Folha da Cidade, Duque de Caxias, Ano II, n.113, 24 ago. 1958, p.01).

Se em junho já eram quatro meses de atraso no pagamento dos salários, em agosto já deveriam ser 06 (seis) meses. Ou então, depois que se pagou dois meses de atraso, começaram a atrasar novamente. Ao que se vê, a Prefeitura Municipal de Caxias relegava a segundo plano a Educação no município; tanto é que além de não se investir na criação de escolas ou na contratação de professoras(es) através de concurso, ainda atrasava o pagamento dos seus salários.

Em artigo do dia 13 de julho de 1958 foram apontados, resumidamente, alguns momentos de entrevista que o Prof. Silas Neves fez com a então Inspetora Municipal de Ensino, D. Regina Tescaro Sampaio, em que a mesma afirmava que o que atrapalhava o ensino na época era a política. Segundo o articulista, a mesma apenas apontou para os problemas da educação em Caxias, mas não os dissecou ou propôs soluções para os mesmos. Ao contrário, chegou a afirmar que se tratava de problemas insolúveis. (Folha da Cidade, 13 jul. 1958, p.02). Se a própria Inspetora de Ensino do município de Duque de Caxias percebia um ensino feito de "trampolim para se galgar posições políticas, cargos eletivos ou de confiança" e ainda era pessimista quanto a uma saída ou enfrentamento para este tipo de atitude, ao se demonstrar passiva e conformada com a situação, então não restava mesmo muito a se fazer. O problema da interferência da política, mais especificamente com as indicações a cargos, as denúncias à existência de professoras leigas e ainda a questão dos salários é trazido à imprensa por Ciro de Paiva: 
Focalizemos Caxias no que toca ao ensino primário no aspecto do magistério. Comecemos por reconhecer ser uma classe muito sacrificada. Sem dúvida alguma qualquer operário garantido pela legislação trabalhista é mais favorecido pelo salário e pela assistência que uma professôra de Caxias. Isso serve para mostrar não só a grande injustiça que se faz ao magistério primário, mas também manifesta a pouca compreensão que se tem por uma classe das mais úteis para a sociedade.

A causa principal, diga-se de passagem, dêsse desprezo pelo magistério é a interferência da política nessa classe que por sua sublime finalidade de estar fora e acima da política. E é a política também a culpada da nomeação de certas professôras que deveriam estar com os alunos aprendendo o alfabeto.

Não obstante êsse senão, o professorado primário das Escolas Municipais de Caxias vem exercendo a profissão de modo até heróico. Heróico, sim. Porque vencer em lotação (digamos melhor, lataria rodante) ou a pé as esburacadas, sujas e lamacentas ruas de Caxias; passar horas e horas em casebres sem ar, sem luz, escaldantes, sem instalações sanitárias condignas, sem água, apresentando diàriamente o quadro triste de uma população faminta, de criancinhas que saem de casa sem comer, e, acima de tudo, recebendo, de cinco em cinco meses ou em delongas maiores, o mais parco que lhes manda a Prefeitura, tudo isso é um pouco acima das fôrças humanas. De muitas Diretoras sei que lavam os sanitários da escola, cozinham a sopa para os alunos, pedem esmola nos açougues ou nas quitandas para dar algum alimento às criancinhas, porque muitas desmaiam na escola porque não se alimentam. Tudo isso somado às humilhações e às vinganças políticas, é algo de extraordinário. E tanto isso mostra a abnegação dessas heroínas ocultas que, se tivessem um amparo maior do Município ou do Estado (ambos arrecadam milhões e milhões que são desbaratados com esses parasitas dos cofres públicos que vão às repartições apenas receber as gordas mensalidades), dar-nos-iam um ensino primário mais eficiente:

Justiça se faça à Câmara de Vereadores que acaba de aprovar o aumento de subsídio das professôras, ato tardio, mas necessário.

Com um magistério primário mais insentivado, mais respeitado, mais acatado pelas autoridades, fora das vinganças políticas ou dos pedidos dos políticos, Caxias, certamente deixaria de ser [...] essa imensa desorganização em crescimento acelerado, para se tornar uma terra civilizada. E o ensino primário sendo o fundamento da civilização (PAIVA, Ciro de. Razões da Razão - Professôras de Caxias. Folha da Cidade, Duque de Caxias, Ano III, n.123, 02 nov. 1958, p.04).

Para além dos diversos problemas, Ciro Paiva chama a atenção quanto à precariedade física com que as escolas em geral teimavam em funcionar; aponta para a situação de miséria em que vivia a maioria das crianças que frequentavam o ensino primário público, mais especificamente o municipal e ainda os malabarismos que a categoria docente fazia para driblar todos esses problemas e outros ainda. Este era o retrato da educação em meados dos anos 1960 em Duque de Caxias. Após esse mergulho naquilo que a imprensa escrita veiculou em termos educacionais, os elementos encontrados no interior das escolas criadas e dirigidas ali pelas Irmãs Franciscanas de Dillingen ou ficam mais evidenciados, ou têm seu valor aumentado relativamente aos elementos das outras escolas ou diante dos diversos problemas da Baixada Fluminense em termos de educação. O que demandaria um outro trabalho de pesquisa. 


\section{Referências}

CAPELATO, Maria Helena Rolim. Propaganda política e controle dos meios de comunicação. PANDOLFI, Dulce. (Org.) Repensando o Estado Novo. Rio de Janeiro: Ed. Fundação Getúlio Vargas, 1999, pp.167-178.

DINIZ, J. Péricles. O Papel do Jornal na construção social de identidades. IV Enecult Encontro de Estudos Multidisciplinares em Cultura. UFBa, Salvador-BA. Maio de 2008. Hht://WWW.cult.ufba.br/enecult2008/14430.pdf.

LUSTOSA, Elcias. O Texto da Notícia. Brasília-DF: Editora Universidade de Brasília, 1996.

SILVA, Vivian Batista da. Uma história das leituras para professores: análise da produção e circulação de saberes especializados nos manuais pedagógicos (1930-1971). Revista Brasileira de História da Educação, Campinas-SP: Editora Autores Associados, SBHE, julho/dezembro 2003, n.6, pp.29-58.

SOBRINHO, Barbosa Lima. O Problema da Imprensa. Prefácio de Alberto Dines. $3^{\text {a }}$ Ed. São Paulo: Edusp: Com-Arte, 1997.

ZICMAN, Renée Barata. História através da Imprensa - algumas considerações metodológicas. Projeto História, n.4, PUC-sp, JUNHO/1985.

\footnotetext{
${ }^{1}$ Mestre em História e Doutora em Educação pela Universidade Federal de Uberlândia.

2 Doutor em História pela USP. Professor dos Programas de Pós-Graduação em Educação da Universidade Federal de Uberlândia e da Universidade de Uberaba.

${ }^{3}$ Em 25 de agosto de 1950 era fundado "O Municipal" (Semanário); foi criado o Jornal "Fôlha de Caxias", em 25 de agôsto de 1953 - sendo o órgão oficial da Associação Comercial de Duque de Caxias (Semanário); Em julho de 1956 o Jornal "Folha de Caxias" passa a denominar-se "Folha da Cidade", mantendo-se como ano 3, porém, reiniciando a numeração; a partir de junho de 1957 apresenta nova reforma gráfica, retornando ao ano 1, porém, mantendo sequencia da numeração anterior; "Tribuna de Caxias".

${ }^{4}$ Os jornais que existiam nessas duas décadas eram: Correio de Iguassú, em Nova Iguassu; Jornal do Povo, em São João de Meriti e Duque de Caxias.

5 AQUINO, Custódio. A "Folha" Escolar. Folha de Caxias, Duque de Caxias, Ano II, n.55, 12 dez. 1954, p.02; AQUINO, Aquino. A "Folha" Escolar. Folha de Caxias, Duque de Caxias, Ano II, n.57, 08 mai. 1955, p.04; Educação e Cultura. Folha da Cidade, Duque de Caxias, Ano II, n.112, 17 ago. 1958, p.02.

6 AQUINO, Custódio. A "Folha" Escolar. Folha de Caxias, Duque de Caxias, Ano II, n.60, 29 mai. 1955, p.06; PEREIRA, Prof. Roberto. A "Folha" Escolar. Folha de Caxias, Duque de Caxias, Ano II, n.63,19 jun. 1955, p.02; Educação e Cultura. Folha da Cidade, Duque de Caxias, Ano II, n.88, 02 mar. 1958, p.04; Desorganizado o Ensino no Município. A Folha de Caxias, Duque de Caxias, Ano III, n.111, 20 mai. 1956, p.06; COMBAT, E. Problemas de Ensino. Tribuna de Caxias - suplemento de Tribuna de Petrópolis, Duque de Caxias, Ano I, n.20, 26 jan. 1947, p.02.

7 AQUINO, Custódio. A "Folha" Escolar. Folha de Caxias, Duque de Caxias, Ano II, n.64, 26 jun. 1955, p.05; Educação e Cultura. Folha da Cidade, Duque de Caxias, Ano II, n.76, 08 dez. 1957, p.02;

${ }^{8}$ AQUINO, Custódio. A "Folha" Escolar. Folha de Caxias, Duque de Caxias, Ano II, n.66, 10 jul. 1955, p.06; As professoras são assíduas às aulas. Folha da Cidade, Duque de Caxias, Ano I, n.11, 03 set. 1956, p.02; Sem corpo docente e péssimo prédio. Folha da Cidade, Duque de Caxias, Ano I, n.14, 24 set. 1956, p.05.

${ }^{9}$ Recomendações por parte de pessoas importantes. Nome que se dá às pessoas importantes que fazem uma recomendação.

${ }^{10}$ Há que se estabelecer, a partir de algumas nomenclaturas que aparecerão ao longo do texto, quem eram ou quais as condições de trabalho das contratadas ou extranumerárias ou interinas, que seriam aquelas professoras que não pertenciam ao quadro efetivo ou permanente dos servidores do Estado ou do Município, aquelas que exerceriam posições provisórias na falta ou impedimento do funcionário efetivo, ou seja, seriam passageiras, temporárias, que serviam temporariamente (lembrando que estas conseguiam cargos ou vagas nas escolas
} 
através de indicações ou pistolões); e as concursadas ou efetivas, as quais sendo habilitadas com concurso por provas públicas, pertenceriam ao quadro de servidores. As regentes de classe seriam aquelas professoras responsáveis por uma disciplina ou uma turma, no caso do então ensino primário. As adjuntas viriam em auxílio do trabalho das regentes. Ainda havia as catedráticas, que eram as professoras titulares ou efetivas, mas de cursos secundários ou superiores.

${ }^{11}$ Em 13 de agosto continuava sendo veiculado na imprensa o problema da falta de professoras no Grupo Escolar, com quatro classes de alunos sem poder frequentar as aulas e centenas de outros sem vagas, por falta de espaço. Um Grupo Escolar público apenas tornava-se insuficiente. (Continua falta de professoras no Grupo Escolar. Folha da Cidade, Duque de Caxias, Ano I, n.7, 13 ago. 1956, p.01).

${ }^{12}$ De Mangaratiba até Duque de Caxias são 93,1 km percorridos em 1 hora e 38 minutos pela rodovia Rio-Santos; ou 102 km percorridos em 1 hora e 31 minutos pelas rodovias Rio-Santos e Presidente Dutra. Vale esclarecer que entre São João de Meriti e Duque de Caxias não há mais divisão geográfica, sendo que do centro de uma cidade ao centro da outra é possível percorrer em uns 15 minutos.

${ }^{13}$ Educação e Cultura. Folha da Cidade, Duque de Caxias, Ano II, n.92, 30 mar. 1958, p.04; Educação e Cultura, Folha da Cidade, Duque de Caxias, Ano II, n.93, 06 abr. 1958, p.02; Educação e Cultura, Folha da Cidade, Duque de Caxias, Ano II, n.94, 13 abr. 1958, p.03; Educação e Cultura. Folha da Cidade, Duque de Caxias, Ano II, n.97, 04 mai. 1958, p.02; Educação e Cultura. Folha da Cidade, Duque de Caxias, Ano II, n.99, 18 mai. 1958, p.05.

${ }^{14}$ Educação e Cultura... Folha da Cidade, Duque de Caxias, Ano II, n.102, 07 jun. 1958, p.06.

Recebido em fevereiro de 2012

Aprovado em abril de 2012 